\title{
Simultaneous Fourth Order Derivative Spectrophotometric Determination of Cobalt, Nickel and Copper Using Anthrone Phenylhydrazone (APH)
}

\author{
V. VEERANNA*, V. SURYANARAYANA RAO and J. N. BALARAJU \\ *Department of Chemistry, Sri Krishnadevaraya University, Anantapur -515003, India \\ National Aerospace Laboratories, Bangalore, India \\ veerachemistry@yahoo.com
}

Received 24 May 2012 / Accepted 13 June 2012

\begin{abstract}
The reagent anthrone phenylhydrazone (APH) is used for the simultaneous determination of $\mathrm{Co}(\mathrm{II}), \mathrm{Ni}$ (II) \& $\mathrm{Cu}$ (II) by fourth order derivative spectrophotometric method. The reagent $\mathrm{APH}$ gives light yellow colour with $\mathrm{Co}$ (II), $\mathrm{Ni}$ (II) \& $\mathrm{Cu}$ (II) solution in basic medium. The maximum peaks were observed between $426.3-625 \mathrm{~nm}$ for $\mathrm{Co}$ (II), $\mathrm{Ni}$ (II) \& $\mathrm{Cu}$ (II) in basic buffer solution of $\mathrm{pH} 10$. The molar absorptivity and Sandell's sensitivity of $\mathrm{Co}(\mathrm{II}), \mathrm{Ni}$ (II) \& $\mathrm{Cu}$ (II)-APH complexes are computed, the molar absorptivity are $1.5 \times 10^{4} \mathrm{~L} / \mathrm{mol} / \mathrm{cm}, 2.0 \times 10^{4} \mathrm{~L} / \mathrm{mol} / \mathrm{cm}$ and $2.163 \times 10^{4} \mathrm{~L} / \mathrm{mol} / \mathrm{cm}$ respectively. The Sandell's sensitivity are $0.0066 \mu \mathrm{g} / \mathrm{cm}^{2}, 0.005 \mu \mathrm{g} / \mathrm{cm}^{2}$ and $0.0026 \mu \mathrm{g} / \mathrm{cm}^{2}$ respectively. The stability constant of Co(II), Ni(II) \& $\mathrm{Cu}(\mathrm{II})$ - $\mathrm{APH}$ complexes are $1.530 \times 10^{5}, 2.486 \times 10^{4}$ and $2.96 \times 10^{4}$ respectively. The effect of various concentrations of $\mathrm{Co}$ (II), $\mathrm{Ni}$ (II) \& $\mathrm{Cu}$ (II) ions on amplitude also studied. The samples of grape leaves, sesame, laver, mung bean and alloy samples were analyzed by the proposed method. The results of the food samples and alloy samples are good agreement with the results of APARI, AAS methods.
\end{abstract}

Keywords: APH, Simultaneous spectrophotometry, Cobalt(II), Nickel(II), Copper(II)

\section{Introduction}

Anothrones are known as carcinogenic compounds. Anthrone derivatives are found to have biological activity ${ }^{1}$. These compounds have an azomethine nitrogen atom and this is responsible for their reactivity with a number of transition metal ions which form colored complexes. Its derivatives such as anthralin and anthraquinone, their functions were studied with the inner mitochondrial membrane. Anthralin readily oxidizes to anthralin dimer and anthraquinone; these compounds have also been identified as skin metabolites ${ }^{2-4}$. Solubilities of some 9-anthrone derivatives and aminoanthraquinone derivatives in supercritical carbon dioxide were studied using a simple and reliable static method ${ }^{5-6}$. Anthranoid laxatives are the most commonly used purgatives in the therapy of acute and chronic constipation ${ }^{7-8}$. Further the metal complexes formed with these reagents are of great medicinal value in the treatment of diseases like colorectal cancer, psoriasis, chronic constipation, tumor related problems regarding ${ }^{9-16}$. In this article, the authors present fourth derivative spectrophotometric method for the simultaneous determination of cobalt, nickel and copper. 


\section{Experimental}

The reagent anthrone phenylhydrazone was prepared by simple condensation of anthrone with phenyhydrazine by adopting the standard procedure. The structure of compound is given below, $\mathrm{NNHC}_{6} \mathrm{H}_{5}$ [Anthrone phenylhydrazone (APH)].<smiles>C=C1c2ccccc2Cc2ccccc21</smiles>

The structure has been established based on IR, mass and NMR spectra. The m.p. of APH is $145-149{ }^{\circ} \mathrm{C}$.

Solutions preparation

Buffer solutions are prepared using $\mathrm{HCl}, \mathrm{CH}_{3} \mathrm{COOH}$ and $\mathrm{NaOAC}$ in acidic medium and $\mathrm{NH}_{4} \mathrm{OH}, \mathrm{NH}_{4} \mathrm{Cl}$ in basic medium.

\section{Preparation of metal and reagent solutions}

The standard $\mathrm{Co}(\mathrm{II}), \mathrm{Ni}(\mathrm{II})$ and $\mathrm{Cu}(\mathrm{II})$ solutions were prepared using analytical reagent grade $\mathrm{CoCl}_{2} \cdot 6 \mathrm{H}_{2} \mathrm{O}, \mathrm{NiCl}_{2} \cdot 6 \mathrm{H}_{2} \mathrm{O}$ and $\mathrm{CuSO}_{4} \cdot 2 \mathrm{H}_{2} \mathrm{O}$. Appropriate quantity of APH is dissolved in DMF for making $0.01 \mathrm{M}$ reagent solution.

\section{Procedure}

\section{Preparation of standard derivative spectrum}

$4 \mathrm{~mL}$ of basic buffer solution of $\mathrm{pH} 10$, varying concentrations of each of the metal solutions of $\mathrm{Co}(\mathrm{II}), \mathrm{Ni}(\mathrm{II})$ and $\mathrm{Cu}(\mathrm{II}), 6 \mathrm{~mL}$ of $10^{-3} \mathrm{M}$ of $\mathrm{APH}$ are taken in a $25 \mathrm{~mL}$ volumetric flask, the contents are made up to the mark with double distilled water and the amplitudes of these solutions were measured between $350-750 \mathrm{~nm}$ against reagent blank.

Shimdzu 160A UV-visible spectrophotometer (Japan) equipped with $1 \mathrm{~cm}$ quartz cell was used in these investigations for making amplitude measurements. A pH meter ELICO $\mathrm{L}_{1}-120$ (Hyderabad) is used to make $\mathrm{pH}$ measurements.

\section{Preparation and analysis of samples}

Food samples or alloy samples were weighed accurately and digested with nitric acid and perchloric acid for determination of $\mathrm{Co}, \mathrm{Ni}$ and $\mathrm{Cu}$. The residue was dissolved with $10 \mathrm{~mL}$ double distilled water for determination. $3 \mathrm{~mL}$ of the digested sample solution, $4 \mathrm{~mL}$ of basic buffer solution of $\mathrm{pH} 10$ and $6 \mathrm{~mL}$ of $\mathrm{APH}$ reagent were taken into a $25 \mathrm{~mL}$ volumetric flask. The derivative spectra of analytes in the sample were recorded using the same procedure. According to the concentrations and amplitudes of standard solutions, the contents of the sample can be calculated from derivative spectrum obtained from sample.

\section{Results and Discussion}

\section{Derivative spectra of $\mathrm{Co}, \mathrm{Ni}$ and $\mathrm{Cu}$ complexes}

The zero order spectrum of a mixture containing cobalt, nickel and copper in presence of APH gives only one peak, no resolution takes place and hence simultaneous determination is not possible and is shown in Figure 1. Hence we have made an attempt to use first, second and third order derivative spectra but, no fruitful results obtained. Finally we have made an attempt to use a $4^{\text {th }}$ order derivative spectrum for possible simultaneous determination of the three metal ions and it is shown in Figure 2. 


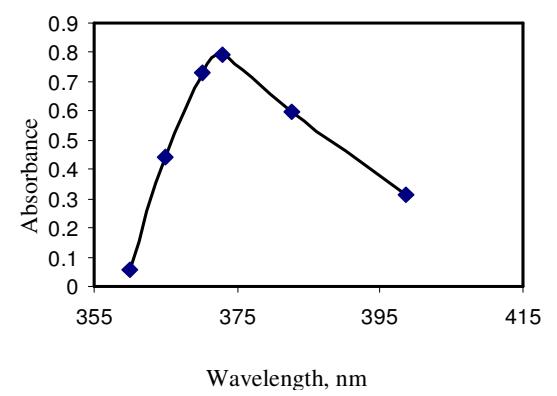

Figure 1. Zero order spectrum of $\mathrm{Co}(\mathrm{II})+$ $\mathrm{Ni}(\mathrm{II})+\mathrm{Cu}(\mathrm{II})$ in presence of $\mathrm{APH}$. $[\mathrm{Co}(\mathrm{II})]=[\mathrm{Ni}(\mathrm{II})]=[\mathrm{Cu}(\mathrm{II})] \quad 1 \times 10^{-5} \mathrm{M}$; $[A P H]=2.4 \times 10^{-4} \mathrm{M}, \mathrm{pH}=10$

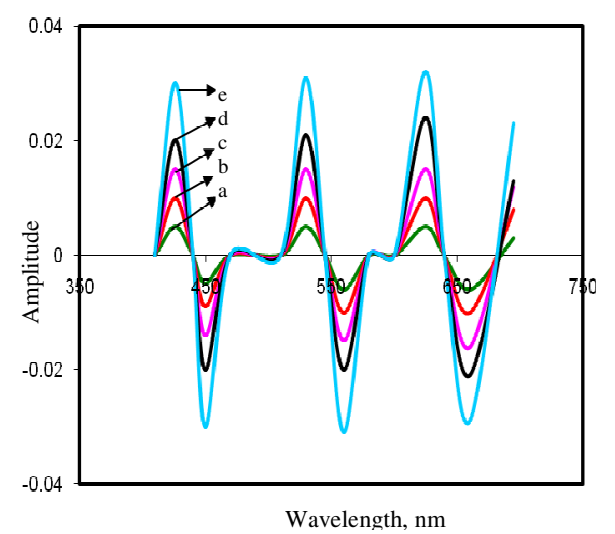

Figure 2. $4^{\text {th }}$ Order derivative spectrum of $\mathrm{Co}(\mathrm{II})+\mathrm{Ni}(\mathrm{II})+\mathrm{Cu}(\mathrm{II})$ in presence of $\mathrm{APH}$ $[\mathrm{Co}(\mathrm{II})]=[\mathrm{Ni}(\mathrm{II})]=[\mathrm{Cu}(\mathrm{II})]=1 \times 10^{-5} \mathrm{M},[\mathrm{APH}]$ $=2.4 \times 10^{-4} \mathrm{M}, \mathrm{pH}=10 ;$ a) $0.5 \mathrm{~mL}$ of $\mathrm{Co}(\mathrm{II}), \mathrm{Ni}(\mathrm{II})$ and $\mathrm{Cu}(\mathrm{II})$ each, b) $1.0 \mathrm{~mL}$ of $\mathrm{Co}(\mathrm{II}), \mathrm{Ni}(\mathrm{II})$ and $\mathrm{Cu}(\mathrm{II})$ each, $\mathrm{c}) 1.5 \mathrm{~mL}$ of $\mathrm{Co}(\mathrm{II}), \mathrm{Ni}(\mathrm{II})$ and $\mathrm{Cu}(\mathrm{II})$ each, d) $2.0 \mathrm{~mL}$ of $\mathrm{Co}(\mathrm{II}), \mathrm{Ni}(\mathrm{II})$ and $\mathrm{Cu}(\mathrm{II})$ each, e) $2.5 \mathrm{~mL}$ of $\mathrm{Co}(\mathrm{II}), \mathrm{Ni}(\mathrm{II})$ and $\mathrm{Cu}(\mathrm{II})$ each

The $4^{\text {th }}$ order derivative spectra are recorded in one case keeping Co(II) constant and varying both $\mathrm{Ni}$ (II) \& $\mathrm{Cu}$ (II) concentration and is shown in Figure 3. In the second case the $\mathrm{Ni}(\mathrm{II})$ concentration is kept constant and both $\mathrm{Co}(\mathrm{II}) \& \mathrm{Cu}$ (II) concentrations are varied shown in Figure 4. In the third case the $\mathrm{Cu}$ (II) concentration is kept constant and both $\mathrm{Ni}$ (II) $\&$ Co(II) concentrations are varied shown in Figure 5.

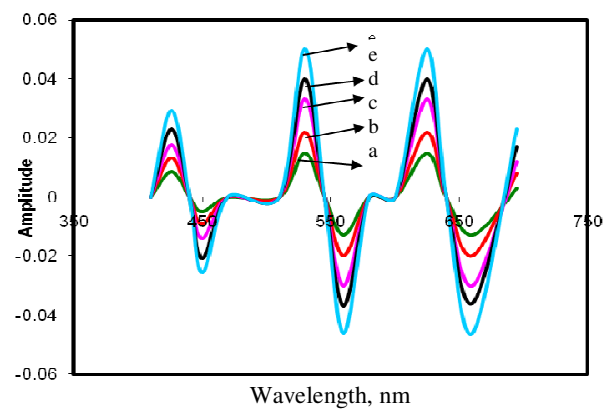

Figure 3. $4^{\text {th }}$ order derivative spectrum of $\mathrm{Co}(\mathrm{II})+\mathrm{Ni}(\mathrm{II})+\mathrm{Cu}(\mathrm{II})$ in presence of $\mathrm{APH}$. Cobalt concentration is kept constant by varying concentration of both $\mathrm{Ni}^{2+}$ and $\mathrm{Cu}^{2+} .[\mathrm{Co}(\mathrm{II})]=$ $[\mathrm{Ni}(\mathrm{II})]=[\mathrm{Cu}(\mathrm{II})]=1 \times 10^{-5} \mathrm{M},[\mathrm{APH}]=2.4 \times 10^{-4} \mathrm{M}$, $\mathrm{pH}=10 ;$ a) $0.5 \mathrm{~mL}$ of $\mathrm{Co}(\mathrm{II}), 1.0 \mathrm{~mL}$ of $\mathrm{Ni}(\mathrm{II})$ and 1.0 $\mathrm{mL}$ of $\mathrm{Cu}(\mathrm{II})$; b) $1.0 \mathrm{~mL}$ of $\mathrm{Co}(\mathrm{II}), 1.5 \mathrm{~mL}$ of $\mathrm{Ni}(\mathrm{II})$ and $1.5 \mathrm{~mL}$ of $\mathrm{Cu}(\mathrm{II}) ; \mathrm{c}) 1.5 \mathrm{~mL}$ of $\mathrm{Co}(\mathrm{II}), 2.0$ $\mathrm{mL}$ of $\mathrm{Ni}(\mathrm{II})$ and $2.0 \mathrm{~mL}$ of $\mathrm{Cu}(\mathrm{II}) ; \mathrm{d}) 2.0 \mathrm{~mL}$ of $\mathrm{Co}(\mathrm{II}), 2.5 \mathrm{~mL}$ of $\mathrm{Ni}(\mathrm{II})$ and $2.5 \mathrm{~mL}$ of $\mathrm{Cu}(\mathrm{II}) ; \mathrm{e}) 2.5$ $\mathrm{mL}$ of $\mathrm{Co}(\mathrm{II}), 3.0 \mathrm{~mL}$ of $\mathrm{Ni}(\mathrm{II})$ and $3.0 \mathrm{~mL}$ of $\mathrm{Cu}(\mathrm{II})$

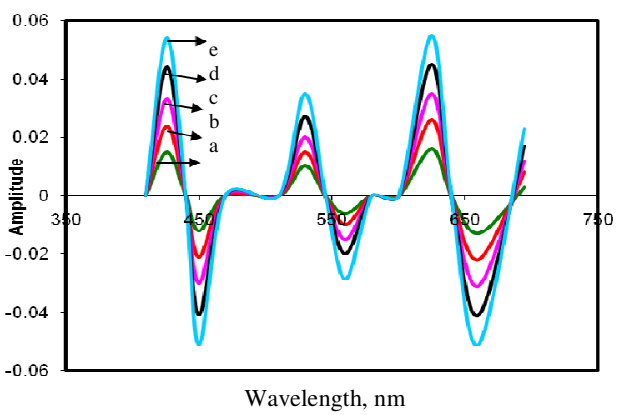

Figure 4. $4^{\text {th }}$ order derivative spectrum of $\mathrm{Co}(\mathrm{II})+\mathrm{Ni}(\mathrm{II})+\mathrm{Cu}$ (II) in presence of $\mathrm{APH}$. Nickel concentration is kept constant by varying concentration of both $\mathrm{Co}^{2+}$ and $\mathrm{Cu}^{2+}$. [Co(II)] = $[\mathrm{Ni}(\mathrm{II})]=[\mathrm{Cu}(\mathrm{II})]=1 \times 10^{-5} \mathrm{M},[\mathrm{APH}]=2.4 \times 10^{-4}$ $\mathrm{M}, \mathrm{pH}=10$; a) $1.0 \mathrm{~mL}$ of $\mathrm{Co}(\mathrm{II}), 0.5 \mathrm{~mL}$ of $\mathrm{Ni}(\mathrm{II})$ and $1.0 \mathrm{~mL}$ of $\mathrm{Cu}(\mathrm{II}) ; b) 1.5 \mathrm{~mL}$ of $\mathrm{Co}(\mathrm{II}), 1.0 \mathrm{~mL}$ of $\mathrm{Ni}(\mathrm{II})$ and $1.5 \mathrm{~mL}$ of $\mathrm{Cu}(\mathrm{II})$; c) $2.0 \mathrm{~mL}$ of $\mathrm{Co}(\mathrm{II})$, $1.5 \mathrm{~mL}$ of $\mathrm{Ni}(\mathrm{II})$ and $2.0 \mathrm{~mL}$ of $\mathrm{Cu}(\mathrm{II}) ; \mathrm{d}) 2.5 \mathrm{~mL}$ of $\mathrm{Co}(\mathrm{II}), 2.0 \mathrm{~mL}$ of $\mathrm{Ni}(\mathrm{II})$ and $2.5 \mathrm{~mL}$ of $\mathrm{Cu}(\mathrm{II}) ; \mathrm{e}) 3.0$ $\mathrm{mL}$ of $\mathrm{Co}(\mathrm{II}), 2.5 \mathrm{~mL}$ of $\mathrm{Ni}(\mathrm{II})$ and $3.0 \mathrm{~mL}$ of $\mathrm{Cu}(\mathrm{II})$ 


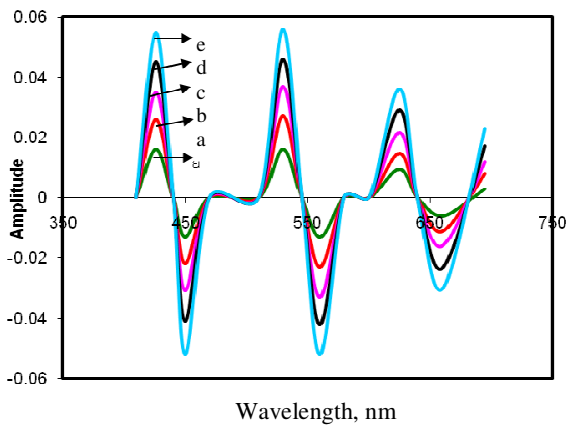

Figure 5. $4^{\text {th }}$ order derivative spectrum of $\mathrm{Co}(\mathrm{II})+\mathrm{Ni}(\mathrm{II})+\mathrm{Cu}(\mathrm{II})$ in presence of APH.

Copper concentration is kept constant by varying concentration of both $\mathrm{Ni}^{2+}$ and $\mathrm{Co}^{2+} \cdot[\mathrm{Co}(\mathrm{II})]=[\mathrm{Ni}(\mathrm{II})]$ $=[\mathrm{Cu}(\mathrm{II})]=1 \times 10^{-5} \mathrm{M},[\mathrm{APH}]=2.4 \times 10^{-4} \mathrm{M}, \mathrm{pH}=10 ;$ a) $1.0 \mathrm{~mL}$ of $\mathrm{Co}(\mathrm{II}), 1.0 \mathrm{~mL}$ of $\mathrm{Ni}(\mathrm{II})$ and $0.5 \mathrm{~mL}$ of $\mathrm{Cu}(\mathrm{II})$; b) $1.5 \mathrm{~mL}$ of $\mathrm{Co}(\mathrm{II}), 1.5 \mathrm{~mL}$ of $\mathrm{Ni}(\mathrm{II})$ and $1.0 \mathrm{~mL}$ of $\mathrm{Cu}(\mathrm{II})$; c) $2.0 \mathrm{~mL}$ of Co(II), $2.0 \mathrm{~mL}$ of $\mathrm{Ni}(\mathrm{II})$ and $1.5 \mathrm{~mL}$ of $\mathrm{Cu}(\mathrm{II})$; d) $2.5 \mathrm{~mL}$ of $\mathrm{Co}(\mathrm{II}), 2.5 \mathrm{~mL}$ of $\mathrm{Ni}(\mathrm{II})$ and $2.0 \mathrm{~mL}$ of $\mathrm{Cu}(\mathrm{II})$; e) $3.0 \mathrm{~mL}$ of $\mathrm{Co}(\mathrm{II}), 3.0 \mathrm{~mL}$ of $\mathrm{Ni}(\mathrm{II})$ and $2.5 \mathrm{~mL}$ of $\mathrm{Cu}(\mathrm{II})$

Graphs are drawn between $\mathrm{Co}(\mathrm{II})$ concentration against peak amplitude, $\mathrm{Ni}$ (II) concentration against peak amplitude and $\mathrm{Cu}(\mathrm{II})$ concentration against peak amplitude. Linear graphs are obtained in all the three cases and shown in the Figures 6,7 and 8. Hence using the fourth order derivative spectrophotometric method, we can determine Co in presence of $\mathrm{Ni}$ and $\mathrm{Cu}$ and vice-versa.

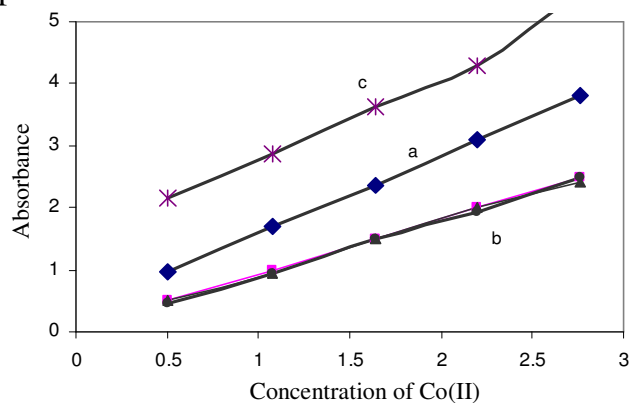

Figure 6. $4^{\text {th }}$ order derivative amplitude $v s$. concentration of $\mathrm{Co}(\mathrm{II}) \mathrm{pH}=10$, a=peak; $\mathrm{b}=$ valley; $\mathrm{c}=$ peak + valley

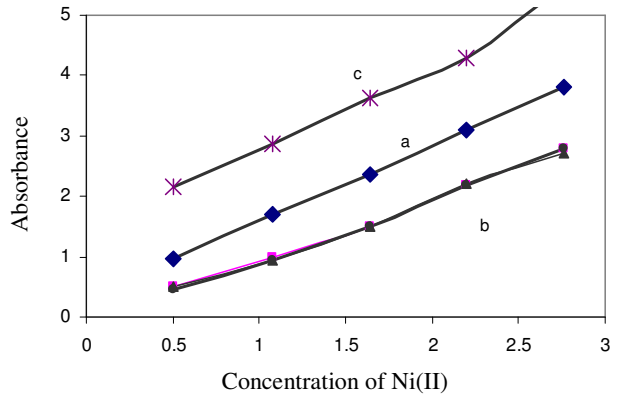

Figure 7. $4^{\text {th }}$ order derivative amplitude $v s$. concentration of $\mathrm{Ni}(\mathrm{II}) \mathrm{pH}=10$, a=peak; $\mathrm{b}=$ valley; $\mathrm{c}=$ peak + valley

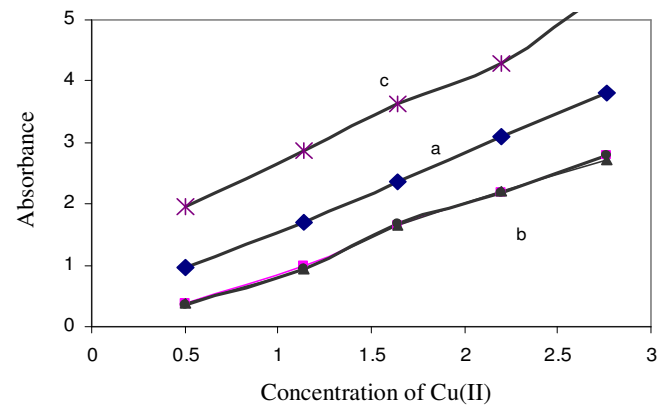

Figure 8. $4^{\text {th }}$ order derivative amplitude $v$ s. concentration of $\mathrm{Cu}(\mathrm{II}) \mathrm{pH}=10$, a=peak; $\mathrm{b}=$ valley; $\mathrm{c}=$ peak + valley 


\section{Influence of the variables}

APH is a kind of high sensitive carcinogenic reagent and it can form colored complexes with many transition metals in neutral and basic medium. The experiments are carried out in the $\mathrm{pH}$ range 7-12. The results showed that the absorbances of three complexes were highest and the complexes are stable in the $\mathrm{pH}$ range 10-11. The effect of $\mathrm{pH}$ on the absorbances are shown in the Figures-9, 10 and 11. Further $\mathrm{Co}(\mathrm{II}), \mathrm{Ni}(\mathrm{II})$ and $\mathrm{Cu}(\mathrm{II})$ do not form stable complexes in acidic medium. It may be due to the hydrolysis of the reagent or the complex itself. In highly alkaline medium ( $>$ pH11) slow turbidity develops which may be due to formation of hydroxides. Studies relating to the effect of time revealed that the complex is stable for a considerable amount of time.

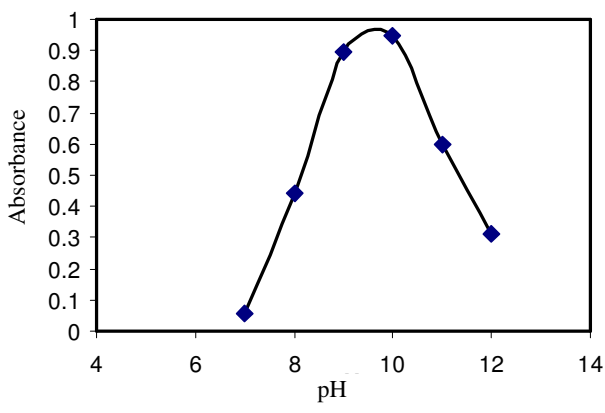

Figure 9. Effect of $\mathrm{pH}$ on the absorbance of cobalt (II)-APH system $[$ Cobalt(II) $]=3 \times 10^{-5} \mathrm{M}$, $[\mathrm{APH}]=2 \times 10^{-4} \mathrm{M}$

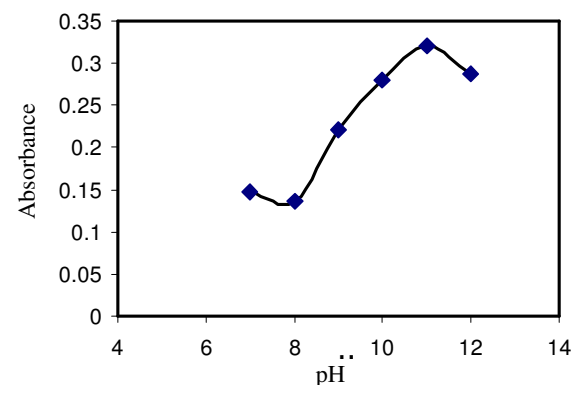

Figure 10. Effect of $\mathrm{pH}$ on the absorbance of nickel (II)-APH system [Nickel(II)] $=3 \times 10^{-5} \mathrm{M},[\mathrm{APH}]=2 \times 10^{-4} \mathrm{M}$

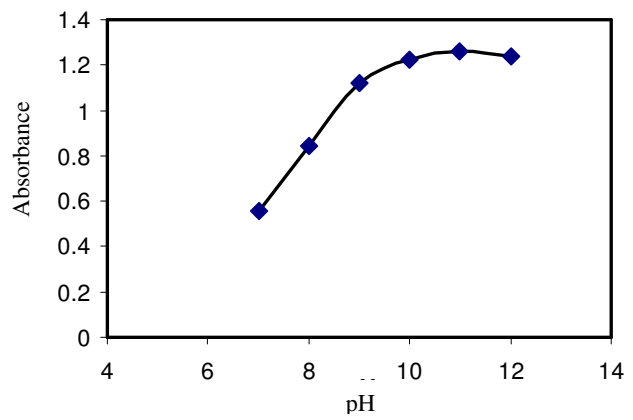

Figure 11. Effect of $\mathrm{pH}$ on the absorbance of copper(II)-APH system $\left[\operatorname{Copper(II)]~}=3 \times 10^{-5} \mathrm{M}\right.$, $[\mathrm{APH}]=2 \times 10^{-4} \mathrm{M}$

The effect of metal ion concentrations $\left(4 \times 10^{-5} \mathrm{M}\right)$ on absorbances is studied by keeping the reagent concentration constant $\left(2.4 \times 10^{-4} \mathrm{M}\right)$. The absorbance values are measured at 373 , 364 and $370 \mathrm{~nm}$ for cobalt, nickel and copper respectively against suitable blank solution containing no metal ion. Linear plots are obtained in all the three cases when graphs are plotted between the metal ion concentration and absorbance and are presented in the Figures-12, 13 and 14. The determination limits were 0.201-1.807, 0.411-4.811 and 0.402$1.810 \mu \mathrm{g} / \mathrm{mL}$ for cobalt, nickel and copper respectively. The stoichiometry of these three metal ions with APH was studied by Job`s method of continuous variation and also the mole ratio method. Both the methods indicated the formation of a 1:1.4, 1:2 and 1:1 complex for cobalt, nickel and copper respectively. By knowing this stoichiometry a 35 fold concentration of APH is taken to react with the three metal ions. 


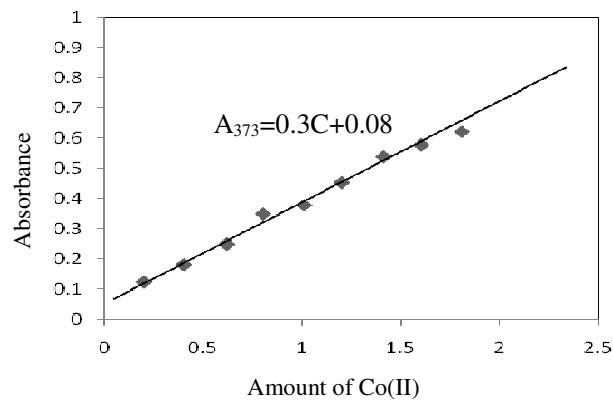

Figure 12. Effect of metal ion concentration on absorbance $\lambda_{\max }=373 \mathrm{~nm},[\mathrm{Co}(\mathrm{II})]=4 \times 10^{-5} \mathrm{M}$, $[\mathrm{APH}]=2.4 \times 10^{-4} \mathrm{M}, \mathrm{pH}=10$

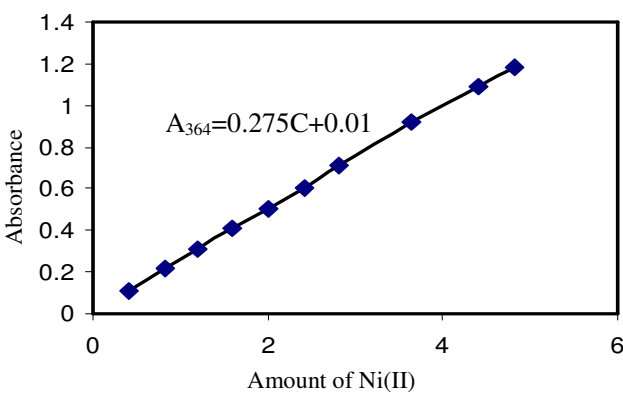

Figure 13. Effect of metal ion concentration on absorbance $\lambda_{\max }=364 \mathrm{~nm},[\mathrm{Ni}(\mathrm{II})]=4 \times 10^{-5} \mathrm{M}$, $[\mathrm{APH}]=2.4 \times 10^{-4} \mathrm{M}, \mathrm{pH}=11$

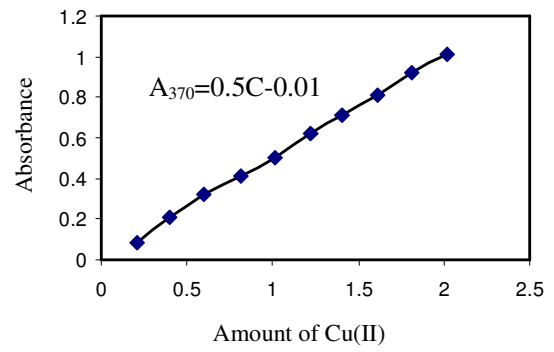

Figure 14. Effect of metal ion concentration on absorbance $\lambda_{\max }=370 \mathrm{~nm},[\mathrm{Cu}(\mathrm{II})]=4 \times 10^{-5} \mathrm{M}$, $[\mathrm{APH}]=2.4 \times 10^{-4} \mathrm{M}, \mathrm{pH}=10.5$

The stability constants of $\mathrm{Co}(\mathrm{II}), \mathrm{Ni}$ (II) \& $\mathrm{Cu}(\mathrm{II})$-APH complexes were calculated from Job`s method. They are found as $1.530 \times 10^{5}, 2.486 \times 10^{4}$ and $2.96 \times 10^{4}$ for $\mathrm{Co}(\mathrm{II}), \mathrm{Ni}(\mathrm{II})$ and $\mathrm{Cu}$ (II) respectively. The effect of interfering species of 23 metal ions commonly found in food samples is investigated. The most interfering ions tested did not interfere in the determination and shown in Table 1.

Table 1. Tolerance limit of foreign ions. Tolerance limit of foreign ions in the determination of $0.841 \mu \mathrm{g} / \mathrm{mL}$ of $\mathrm{Co}(\mathrm{II}), 1.35 \mu \mathrm{g} / \mathrm{mL}$ of $\mathrm{Ni}$ (II) and $0.94 \mu \mathrm{g} / \mathrm{mL}$ of Cu(II) $\mathrm{pH}=10 \lambda_{\max }=364 \mathrm{~nm}$

\begin{tabular}{cccc}
\hline Foreign ion & Tolerance limit, $\mu \mathrm{g} / \mathrm{mL}$ & Foreign ion & Tolerance \\
\hline Thiourea & 94 & $\mathrm{Mn}(\mathrm{IV})$ & 2.54 \\
Tartrate & 319 & $\mathrm{U}(\mathrm{VI})$ & 96.21 \\
Sulfate & 755 & $\mathrm{Ru}(\mathrm{III})$ & 13.20 \\
Phosphate & 163 & $\mathrm{Se}(\mathrm{IV})$ & 116 \\
Fluoride & 17 & $\mathrm{~Pb}(\mathrm{II})$ & 2.53 \\
Chloride & 44.21 & $\mathrm{Cd}(\mathrm{II})$ & 3.84 \\
Iodide & 63.8 & $\mathrm{Zr}(\mathrm{IV})$ & 3.73 \\
Nitrate & 112.23 & $\mathrm{Ti}(\mathrm{IV})$ & 123.18 \\
Oxalate & 16.57 & $\mathrm{Sn}(\mathrm{II})$ & 2.27 \\
EDTA & 316.4 & $\mathrm{Mg}(\mathrm{II})$ & 1.55 \\
Thiosulfate & 55.23 & $\mathrm{Zn}(\mathrm{II})$ & 1.74 \\
Bromide & 440 & $\mathrm{~W}(\mathrm{VI})$ & 745.4 \\
Citrate & 841 & $\mathrm{Pd}(\mathrm{II})$ & 0.55 \\
Acetate & 144.3 & $\mathrm{Hg}(\mathrm{II})$ & 11.19 \\
& & $\mathrm{Fe}(\mathrm{II})$ & 2.65 \\
& & $\mathrm{Mo}(\mathrm{VI})$ & 66.25 \\
\hline
\end{tabular}




\section{Application}

The present method is applied for the determination of three metal ions simultaneously in sesame, laver, soyabean powder and alloy samples. The repeatability and precision of the method were satisfied with RSD in the range of $0.0563-0.0888 \%$ for five determinations. Therefore, the three metal ions can be directly determined after digestion without any pretreatment by the proposed method. Accuracy of the proposed method was validated using a certified reference material of tea and grape leaves (GBW07605 and GBW08501, Chinese Standard material center) (AAS and APARI, Hyderabad). The values determined by the proposed method and the determined values $(n=5)$ of the certified reference material were within the given guarantee values and shown in the Table 2.

Table 2. Analysis of alloy samples

\begin{tabular}{|c|c|c|c|c|c|c|c|c|c|}
\hline \multirow{2}{*}{ Sample } & \multicolumn{3}{|c|}{ ASTM method, \% } & \multicolumn{3}{|c|}{ By Present method, \% } & \multicolumn{3}{|c|}{$\%$ Error } \\
\hline & $\mathrm{Co}(\mathrm{II})$ & $\mathrm{Ni}(\mathrm{II})$ & $\mathrm{Cu}(\mathrm{II})$ & $\mathrm{Co}(\mathrm{II})$ & $\mathrm{Ni}(\mathrm{II})$ & $\mathrm{Cu}(\mathrm{II})$ & $\mathrm{Co}(\mathrm{II})$ & $\mathrm{Ni}(\mathrm{II})$ & $\mathrm{Cu}(\mathrm{II})$ \\
\hline $\begin{array}{l}\mathrm{Co}-\mathrm{Cr} \\
\text { alloy }\end{array}$ & 62.9 & 1.7 & 0.9 & 62.1 & 1.9 & 0.7 & +1.271 & -11.76 & +11.76 \\
\hline $\begin{array}{l}\text { Ni-Cr- } \\
\text { Mo alloy }\end{array}$ & 50.6 & 14.9 & 1.5 & 50.9 & 14.6 & 1.7 & -0.592 & +2.013 & -1.333 \\
\hline $\begin{array}{c}\text { Ground } \\
\text { nut seeds }\end{array}$ & $\begin{array}{r}1.175 \\
\mu \mathrm{g} / \mathrm{mL}\end{array}$ & $\begin{array}{r}4.205 \\
\mu \mathrm{g} / \mathrm{mL}\end{array}$ & $\begin{array}{r}1.248 \\
\mu \mathrm{g} / \mathrm{mL}\end{array}$ & $\begin{array}{r}1.189 \\
\mu \mathrm{g} / \mathrm{mL}\end{array}$ & 4.198 & 1.240 & -1.191 & +0.166 & +0.641 \\
\hline
\end{tabular}

\section{Conclusion}

In this article, a multi-component analysis with $4^{\text {th }}$ order derivative spectrophotometry has been developed. The proposed method has been successfully applied for the simultaneous determination of $\mathrm{Co}, \mathrm{Ni}$ and $\mathrm{Cu}$ in certified reference materials and food samples after digestion without further pretreatment. Compared with the traditional spectrophotometry, the proposed method provides good results for three analytes in terms of accuracy and precision and allows 44 determinations per hour for the digested food samples and the results proved to be satisfactory and meet the criterion of food analysis.

\section{References}

1. Hedge J E and Hofreiter B T, In Carbohydrate Chemistry, 17 Academic Press, New York, 1962.

2. Whistler R L and Be Miller J N, Eds., Methods in Carbohydrate Chemistry, 1962.

3. Thayumanavan B and Sadasivam S, Qual Plant Foods Hum Nutr., 1984, 34, 253.

4. Updegroff D M, Anal Biochem., 1969, 32, 420-424.

5. Ali Reza Karami, Yadollah Yamini, Ali Reza Ghiasvand, Hashem Sharghi and Mojtaba Shamsipur, J Chem Eng Data, 2001, 46(6), 1371-1374.

6. Mojtaba Shamsipur, Ali Reza Karami, Yadollah Yamini and Hashem Sharghi, $J$ Chem Eng Data, 2003, 48(1), 71-74.

7. Kune G A, Kune S, Field B and Watson L F, Dis Colon Rectum., 1988; 31, 507-512.

8. Nusko G, Schneider B, Ernst H, Wittekind C and Hahn E G, Gastroenterol., 1997, 35, 313-318.

9. Patel P M, Selby P J, Deacon J, Chilvers C and McElwain T J, Postgrad Med J., 1989, 65, 216-17.

10. Siegers C P, Hertzberg-Lottin Evon, Otte M and Schneider B, Gut., 1993, 34, 1099-1101. 
11. Jass $\mathrm{J}$ R and Sobin L H, Histological Typing of Intestinal Tumours, WHO International Classification of Tumours, $2^{\text {nd }}$ Edn., Berlin: Springer, 1989.

12. Breslow N E and Day N E, Statistical Methods in Cancer Research, Vol. I -The analysis of case control studies, Lyon: IARC, 1980.

13. Parkin D M, Läärä E and Muir C S, Int J Cancer, 1988, 41,184-197.

14. Thun M J, Calle E E and Namoodiri M M, et al., J Natl Cancer Inst., 1992, 84, 1491-1500.

15. Boeing $\mathrm{H}$ and Wahrendorf J, Internist (Berl), 1991, 32(6), 306-314.

16. Thipyapong K and Suksai C, Bull Korean Chem Soc., 2003, 24(12), 1767-1770. 